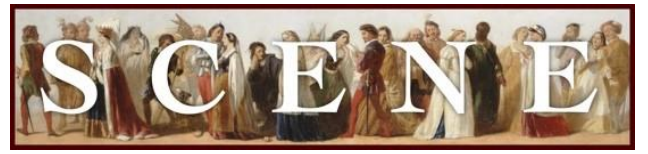

\title{
"Exit Ghost": Hamlet (dir. Austin Pendelton)
}

\author{
by Gavin Hollis. Written on 2015-04-12. Published in 2017 Issue 1.
}

For the production: Hamlet (2015, Classic Stage Company, USA). See production details at the end of the review.

In a ReCent interview for The Guardian, Peter SARsgaArd, Playing the title Character in the Classic Stage Company's production of Hamlet, compares trying to speak "to be or not to be" in such a way that the audience experiences it afresh like "to play[ing] Stairway to Heaven in a way somebody actually listens to the song." Every production of which is haunted by is previous revivals, and perhaps especially for any actor playing Hamlet, "the Everest of acting roles". To give space for an audience to experience Hamlet anew is a challenge awaiting all productions of the play.

One way that Austin Pendleton's production attempts to exorcise the ghosts of Hamlets past is by removing the ghost of Hamlet's father. At the beginning of the production, performed in modern dress on the small thrust stage of the Classic Stage Company theatre, wedding guests enter and sit around the circular table that dominates center stage: in a nod perhaps to another haunted Shakespeare play, Macbeth, one table setting, next to Hamlet, is empty. The wedding party sits, still but for Hamlet, whose gaze is fixed on (presumably) his father's chair (on the next chair over sits his mother, Gertrude, played by Penelope Allen). Simultaneously, the watch assembles around the edges of the stage space, accompanied by Horatio (Austin Jones), and relays what it has seen the previous night, and then is startled by the appearance of Old Hamlet, although the audience never sees the ghost; indeed, the ghost seems to be located in the audience). The simultaneity raises questions: every time the ghost appears, Sarsgaard's prince looks in the same direction. So, is this figure real? Or is the ghost a conjuration of Hamlet's mind?

This question becomes even more pressing when Hamlet goes to find the ghost at the end of act one. Pendleton has cut the beginning of act one scene five: we don't hear the ghost's description of his purgatorial existence and his account of his "murder, most foul" at the hands of his brother. Sarsgaard simply exits downstage left only to return, seconds later, to tell his friends "O wonderful." 
Pendleton's choice recalls Richard Eyre's famous production for the Royal Court (1980), in which Jonathan Pryce's Hamlet became possessed by the ghost of his father and speaks his lines.

Eyre's directorial choice raises questions about the nature of the ghost, and about Hamlet's own mental state-his possession is both ghostly and suggestive of a severe personality disorder in Hamlet. Pendleton floats the possibility that Hamlet fabricates his encounter. The ghost's final "appearance," in the closet scene, feels more like Hamlet being plagued by guilt for his attack on his mother. This sense is present also one scene earlier, when Claudius (Harris Yulin), spooked by The Mousetrap, confesses his sins to heaven. Yet the staging, which mirrors the opening of the production, is framed by Hamlet looking at Claudius, almost as if he is conjuring an image of his uncle at confession to justify his actions (and, subsequently, to justify his decision not to kill his uncle while at prayer).

As with Pryce, then, Sarsgaard's Hamlet is deeply disturbed, but perhaps even more murderously so, given the possibility that Hamlet desires to avenge not so much "his father's death" but rather his mother and uncle's "o'erhasty marriage"-a vengeance plot spurred by an enraged jealousy and justified by a phantasm of Hamlet's own imagining. The Mousetrap, then, is less to catch the conscience of the king but more a not-so-very veiled threat against him (Lucianus, the murderer of Gonzago, is "nephew to the king," after all).

Pendleton's production has a number of neat flourishes. Sarsgaard's Hamlet is on-stage for much of the production even in scenes he doesn't appear in (apart from the twenty minutes or so of stage-time when he is dispatched to England), intently listening, in particular to when he is talked about (which is a lot). Ophelia too is on-stage a great deal, listening in on Hamlet's "too too solid flesh" and reacting with considerable ambivalence to his declaration of the "frailty" of women, and then hearing her father's account of Hamlet's disheveled appearance in her bedchamber. Hamlet even acknowledges her presence prior to "to be or not to be," as if his contemplation of suicide is meant especially for her. Given Ophelia's fate, one senses that her madness is a reflection of, and maybe a product of witnessing, Hamlet's own "antic." The gravedigger and Yorick remain onstage during the Laertes-Hamlet duel, looking on, waiting for new employment: and in Scott Parkinson, who doubles as the gravedigger and as Rosencrantz, and Daniel Morgan Shelley, who doubles as Fortinbras and Guildenstern, haunt the final scene, reminders of the cost of Hamlet's revenge.

Pendleton overuses the motif of having characters on-stage, half-in and half-out of the action, however. Polonius, for example, sits at the wedding banquet table throughout Hamlet's engagement with the ghost, foreshadowing perhaps that he will be the first victim of Hamlet's revenge mission, but his presence is a distraction, especially in a scene which sets the tone for 
this production's reimagining of the play (one might be so intend on wondering what Polonius is sitting there and miss entirely Hamlet's account of meeting the ghost).

But the motif does serve to remind us how prevalent a theme "observation" is in Hamletalthough not in the way that Nicholas Hytner's 2010 production for the National Theatre staged Elsinore as a surveillance state. It also reminds us of our own status as observers of the action, and observers of this very famous, much-performed play. It is telling that Hamlet sees the ghost in the audience. We, an audience who desire to see the play's "carnal, bloody, and unnatural acts," are stand-ins for the ghost, carrying with us the memory of a much-told tale and willing Hamlet to his bloody conclusion, even if the evidence for Claudius' crime, which is never wholly made clear in this production, is equivocal at best. At the very end of the production, Hamlet announces his dying but Sarsgaard's eyes remain open, looking out to the audience, either berating us for our complicity or coming to join us in the land of memory, the land of the dead.

Hamlet, of course, berates his uncle's court as sodden with booze, and Pendleton's builds on this sense to mount an incredibly boozy Hamlet. In Peter Hall's 1992 production, Michael Pennington's Claudius seemed to constantly be accompanied by an amply-filled whisky tumbler. Here, everyone participates in "heavy-headed revel," most notably Hamlet (this production would present the most challenging of drinking games to follow along with). The mood of the production is of people desperately trying to dull pain by making just one more trip to the bar (indeed, upstage left is a bar lit in such a way that recalls another famously haunted space, Stanley Kubrick's Overlook Hotel bar in The Shining). When Hamlet "encounters" the ghost off-stage, he is considerably drunk. Horatio's warning that he will fall from a cliff into the sea is spurred by his concern about the temptations of spirits rather than this particular spirit. Gertrude too seems increasingly half-cut, in particular at Ophelia's madness (scenes which follow on from the trauma of the closet scene, of course), even if she is much more sober when delivering news of her death to Laertes.

Yet for all these interesting ideas, this production was strangely impoverished, particularly in the acting department. Sarsgaard's approach may be in part to blame here. In The Guardian interview Sarsgaard describes how he "changes from moment to moment and night to night. "It's fascinating to see him go through draft after draft after draft of a line, a soliloquy, a scene,' says [Brian] Kulick [artistic director of CSC[. 'Something is always very alive, something is always newly discovered." Some of Sarsgaard's "variety" in the performance I saw was effective, particularly in exchanges with other characters. His first meeting with Rosencrantz and Guildenstern fizzed with nervous energy, and his allusion to "the excellent canopy the air" drew attention to the striking floral arrangement hanging above the stage (and above the dining table in particular), flowers that connote both wedding and funeral, and hence, at this moment, 
at reminder of how dominant the two events are in Hamlet's psyche. Hamlet's erratic, hyped-up performance of Aeneas' account of the Fall of Troy contrasted well with its continuation by more measured, and ultimately more emotive, Player King (Jim Broaddus). However, Sarsgaard's approach to soliloquies (the Led Zeppelin moments, as it were) is erratic, and not in a good way. It is not always clear what he is saying, nor that he is even clear about what he is saying, and his resort to gesticulation and random arm-waving is distracting, especially so given he is playing a character with much to say about overly gestural acting. For all that Sarsgaard wants to experiment with the text, he was not comfortable enough with the language or the character to be able to pick his way through the play on the hoof. His performance was a series of Hamleteffects, lacking in clear through-lines. All musical greats know the rules that they are breaking. Sarsgaard is no Jimmy Page.

This is also one of the most poorly-spoken productions of Shakespeare I have seen, especially from a company whose very name suggests a facility with classical theatre. The production as a whole is plagued by the end-stop. Perhaps in deference to Peter Hall's Playing Shakespeare, the actors repeatedly paused at the end of each line, regardless of where they break lay in the sentence. While obeying line-stops is a useful tool in the actor's armory, and points to key words and concepts that would otherwise be missed if the verse structure is not attended to, over-attentiveness not only leads to samey line-readings but to incomprehensible ones. Indeed, the effect was frequently of actors forgetting lines rather than conveying complex thought-an effect that in the performance I saw was enhanced by several dropped lines, pretty unforgiveable for a production that had been running for two and a half weeks before I saw it. Oh for a Simon Russell Beale, whose 2004 National Theatre version (directed by John Caird) was among the best-spoken Hamlets I've ever seen (or rather heard).

Only occasionally was there inventiveness in speech: while overfussy at the beginning of the production, particularly in his scene with Reynaldo, where his advice to his servant was slow and confusing, Stephen Spinella's Polonius warmed up considerably: both his delivery of "brevity is the soul of wit" and his interactions with Hamlet and Laertes were well-tuned and even touching, even in the character's misguidedness, while his impatience with Hamlet was chillingly evident after the Mousetrap. While occasionally victim of the play's concept, Lisa Joyce presented a sophisticated Ophelia, whose gentle mocking of her father's and brother's advice indicated a women far from the court ingénue of many other productions. Perhaps best of all, Daniel Morgan Shelley and Scott Parkinson, who played many of the minor characters (including Rosencrantz and Guildenstern) found great variation in their line readings, perhaps because the production demanded that they take on multiple different personalities with very little time for costume changes. Their cocky Rosencrantz and Guildenstern differed markedly 
from their precious Players, and provided much needed levity to an otherwise darkly-hued production.

Moreover, without the Ghost scene, and without the certainty of whether or not Claudius has committed his crime, Yulin's Claudius becomes merely a cypher. He is no canny and brutal politician, but rather a projection of Hamlet's psyche. Yulin's stilted line-delivery suggested an actor lost in a concept not of his making. Indeed, if anyone is a ghost in this production, it is him. Only one moment stands out. Upon realizing that he has been instrumental in the death of Gertrude, indeed, sensing that Gertrude drinking from Hamlet's cup is an act of suicide, Claudius welcomes Hamlet's offer to "Drink off this poison [and] / Join my mother." Claudius' devotion to Gertrude here becomes evident, even though the production does not support this sense with any great cohesion elsewhere.

The trouble with this production is that, as Sarsgaard's interview suggests, this Hamlet is staged for people who already know Hamlet. And as staged for the Classic Stage Company, a theatre company known for doing, well, classical theatre, maybe that's understandable. That said, the audience on the day I saw it was diverse, with a number of younger audience members who presumably have fewer, if any, previous Hamlets in their "mind's eye." Quite what the made of play is anybody's guess, but a swath of the audience did not return after the interval.

Indeed, my analysis of the absent ghost suggesting Hamlet's homicidal tendencies, drunken delusions, and parent issues, or the production's affinities between Ophelia and Hamlet, or the space of the audience as "the undiscovered country" are born of repeated engagements with a play I've directed, taught, and seen more times than I can count. I may be haunted by multiple productions (as my own allusions to Hall's, Eyre's, Hytner's, and Caird's bear witness). And even then I'm not sure whether the removal of the ghost is really there to make us question Claudius' crime and Hamlet's psychosis, whether as audience members we become specters carrying with us the memory of Old Hamlet, whether Ophelia "catches" Hamlet's madness from him, or quite what to make of the booziness of Claudius' court. While Pendleton's ideas are often interesting and shed some light about Hamlet and the history of Hamlet, the execution is scattershot, and the performances frequently undercooked. For all the showy moments, I can't help but wonder (to borrow from that other haunted Shakespeare play) whether this production, all sound and fury, really signifies anything much at all.

Gavin Hollis is Associate Professor of English at Hunter College, CUNY. His monograph, The Absence of America: The London Stage 1576-1642 is published by Oxford University Press. 


\section{Production Details}

\section{General}

Title

Year

Theater Company

End Date
Hamlet

2015

Classic Stage Company (USA)

2015-05-10

\section{Cast}

QueEn Gertrude
Player King
LAERTES
Horatio
OpHELIA
ROSENCRANTZ
HAMlet
GUildenstern
POLONIUS
CLAUdiUs

Penelope Allen

JIM BROADDUS

GLENN FITZGERALD

AUSTIN JONES

LISA JOYCE

SCOTT PARKINSON

PETER SARSGAARD

DANIEL MORGAN SHELLEY

STEPHEN SPINELLA

HARRIS YULIN

\section{Creatives}

$\begin{array}{ll}\text { Director } & \text { Austin Pendleton } \\ \text { Costume Designer } & \text { Constance Hoffman } \\ \text { Scenic Design } & \text { Walt Spangler } \\ \text { Lighting Design } & \text { JUstin Townsend } \\ \text { Music and Sound Design } & \text { Ryan Rumery }\end{array}$

